\section{Questões Comentadas da Prova Escrita do Título Superior em Anestesiologia - 2000 (Questão $n^{\circ} 41$ )}

\section{Senhor Editor,}

Tendo recebido o Suplemento 26 (Provas) dessa conceituada publicação, fiquei feliz em mais uma vez poder desfrutar do acesso às questões da Prova Escrita para Título Superior em Anestesiologia, bem como seus respectivos comentários. A abrangência dos assuntos abordados e o rigor com o qual tais questões e suas alternativas propostas são formuladas contribuem para fazer da Sociedade Brasileira de Anestesiologia uma das mais (senão a mais) exigente em termos de formação profissional e organizada sociedade de especialistas desse nosso país. No entanto, se "Medicina e Anestesiologia não são Matemática", deveriam se comportar rigorosamente como tal quando a utilizam.

Refiro-me à questão número 41 da prova escrita do TSA, na qual se interroga a razão pela qual o brônquio direito é mais fácil (provável) de ser intubado seletivamente (acidentalmente ou não) do que o brônquio esquerdo. Segundo o gabarito oficial e a explicação do comentador, a resposta correta é: "Devido ao ângulo menor entre o brônquio direito e a traquéia". No entanto, o ângulo entre o brônquio direito e a traquéia (da ordem de 155 graus, $\alpha$ na figura 1) é efetivamente maior que o ângulo entre o brônquio esquerdo e a traquéia (da ordem de 135 graus, $\beta$ na figura 1).

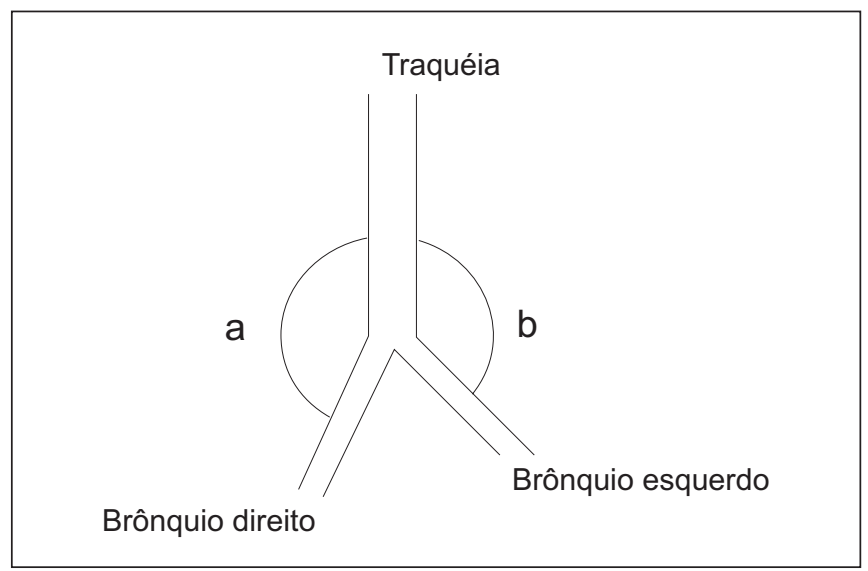

Figura 1

Dessa forma, não concordo com a resposta oficialmente divulgada (nem com o comentário da questão). 25 e 45 graus são os ângulos formados pelos eixos dos brônquios direito e esquerdo respectivamente, com o prolongamento do eixo da traquéia, conforme mostrado na figura 2 , o que é, matematicamente, completamente diferente.
LETTER TO THE EDITOR

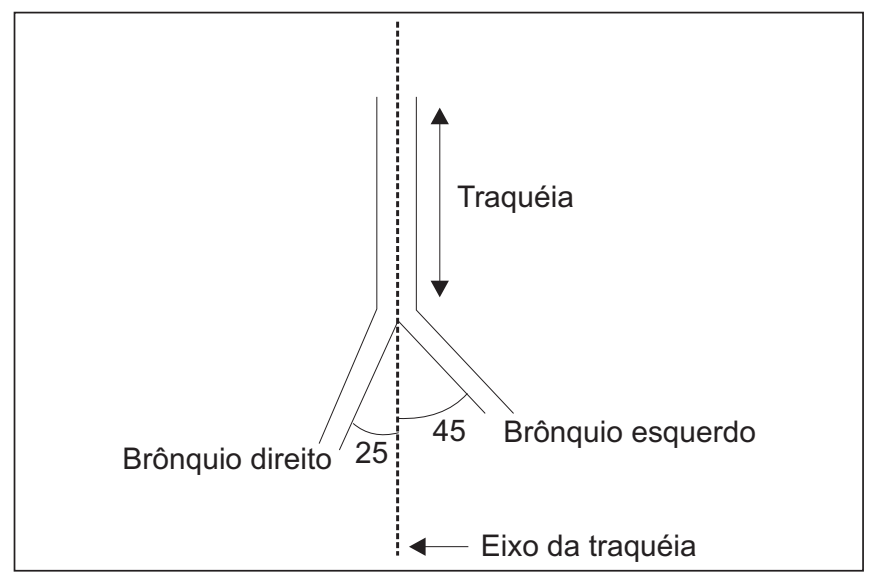

Figura 2

Sem mais para o momento, gostaria de parabenizar a equipe responsável pela edição da Revista Brasileira de Anestesiologia pela qualidade e abrangência dos artigos publicados.

Atenciosamente.

Dante Roberto Eickhoff

Rua Jorge Miranda 104/23 13020-180 Campinas, SP

\section{Réplica}

Em nome da Comissão Examinadora do Título Superior em Anestesiologia quero externar-lhe nossos agradecimentos pela contribuição oferecida em prol do aprimoramento da prova.

A Comissão entende que sua análise é pertinente e a levará em consideração quando da elaboração de futuras questões; considerando-se que a ponderação feita não altera a opção dada como correta.

Sem mais para o momento, renovamos protestos de estima e consideração.
Atenciosamente.

Carlos Alberto de Souza Martins Presidente do CE.TSA/SBA Luiz Fernando de Oliveira Secretário do CE.TSA/SBA 


\section{Commented Questions on the Anesthesiology Board Examination - 2000 (Question 41)}

Editor,

Having received the Supplement 26 (Tests) of this highly respected publication, I was happy in once more being able to have access to the questions of the Superior Title in Anesthesiology Written Test and their related comments. The comprehensiveness of the subjects and the exactness with which such questions and proposed alternatives are formulated contribute to make the Brazilian Society of Anesthesiology one of the most (if not the most) demanding societies in terms of professional qualification and one of the most organized specialists society in our country. However, if "Medicine and Anesthesiology are not Mathematics", they should behave as such when being applied.

I am talking about question number 41 of the TSA written test where it is asked the reason why the right bronchus is easier (probable) to be selectively intubated (accidentally or not) than the left bronchus. According to the official template and the commentator's explanation, the correct answer would be "due to the smaller angle between the right bronchus and the trachea". However, the angle between the right bronchus and the trachea (approximately 155 degrees, $\alpha$ in figure 1) is in fact larger than the angle between the left bronchus and the trachea (approximately 135 degrees, $\beta$ in figure 1 ).

So, I disagree from the officially published answer and its related comment. The angles formed by right and left bronchi axis are 25 and 45 degrees, respectively, with the prolonging of the trachea's axis, according to figure 2 , which is mathematically totally different.

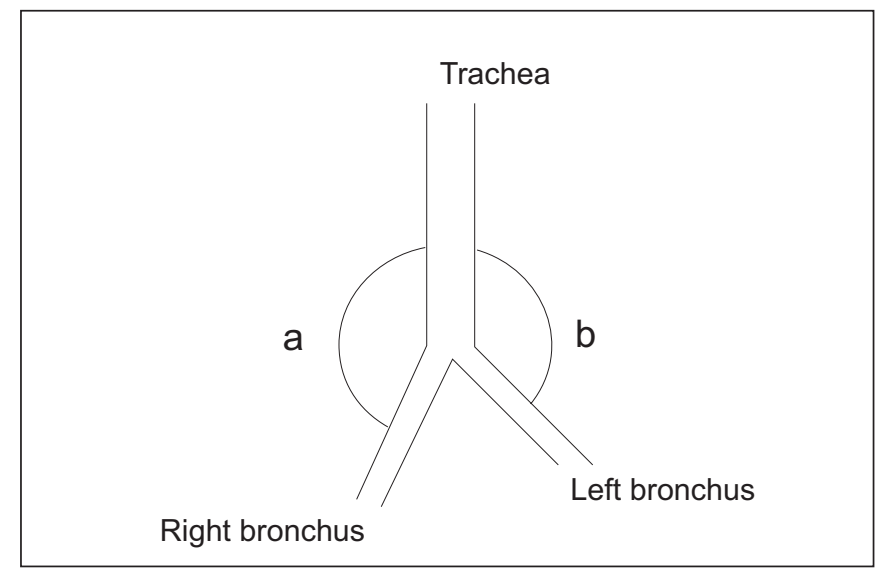

Figure 1

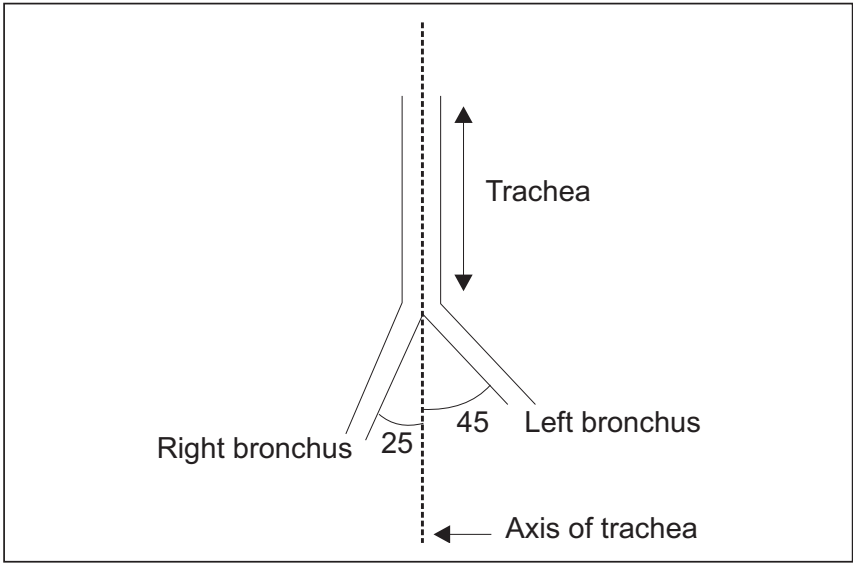

Figure 2

Congratulating the team in charge of the Brazilian Journal of Anesthesiology for the quality and comprehensiveness of its articles I remain.

Yours truly.

Dante Roberto Eickhoff

Rua Jorge Miranda 104/23

13020-180 Campinas, SP

\section{Reply}

On behalf of the Examining Committee of the Superior Title in Anesthesiology, I thank you for your contribution in favor of improving our test.

The Committee understands that your analysis is pertinent and will take it into consideration when preparing future questions, considering that your remarks do not affect the option considered as correct.

Yours truly.

Carlos Alberto de Souza Martins President of EC, TSA/SBA

Luiz Fernando de Oliveira

Secretary of EC, TSA/SBA 